\title{
HEALTH SELF-ASSESSMENT IN PRESENTLY AND PREVIOUSLY PHYSICALLY ACTIVE PEOPLE AGED 45-89 YEARS
}

\author{
KATARZYNA KOTARSKA ${ }^{1}$ MARIA ALICJA NOWAK ${ }^{2}$ \\ University of Szczecin, Faculty of Physical Culture and Health Promotion, Chair of Kinesioprevention', \\ Chair of Prevention and Group Therapy 2
Mailing address: Katarzyna Kotarska, University of Szczecin, Faculty of Physical Culture and Health Promotion, 40B Piastów Ave., 71-065 Szczecin, tel.: +48 91 4442777, fax: +48 91 4442736, e-mail: katarzyna.kotarska@univ.szczecin.pl

\begin{abstract}
Introduction. Health behaviours, such as physical activity, are important elements in human life. They are particularly significant and crucial for the elderly in adapting to the new challenges in their daily life. One important indicator of the health status of individuals in the post-working age is its self-assessment. The aim of the study was to determine the self-assessment of the health status of people aged 45-89 years physically active at present and in the past. Material and methods. The research was based on purposeful sampling and was carried out as part of courses related to the physical mobilisation of elderly people held at the Poznań Academy of Physical Education faculty in Gorzów Wielkopolski and at the Faculty of Physical Culture and Health Promotion at the University of Szczecin. The research involved 300 parents and grandparents of the students taking courses at the two universities. Data were collected by means of a diagnostic survey carried out using questionnaires and interviews. Results. Women constituted the majority of respondents and had a higher self-assessment of their health than the men in each age group. The highest self-assessments were reported by urban dwellers, parents, and younger people. People who were physically active (currently and previously) - practising sports, travelling, going away on holiday, and taking care of their health (by doing rehabilitation or going to a sanatorium) - or professionally active also had a higher self-assessment of their health. Conclusions. Studying the elderly is important not only for diagnosing diseases but also for identifying prevention activities. Knowledge of the types of behaviour that are conducive to health and ways of modifying them, supported by positive behaviour patterns, should contribute to improving the health of society.
\end{abstract}

Key words: health behaviours, elderly, self-assessment, parent and grandparent physical activation projects

\section{Introduction}

The aging of populations caused by prolonged life expectancy and accompanied by a decreasing birth rate is one of the most important demographic processes that characterise modern civilisation. Usually, demographic data on the elderly concern individuals in the very broad $80+$ category, with some less common studies using the 85+ category [1]. A more specific approach would be of greater use to gerontologists, as well as to social and health policymakers.

In health-promoting activities aimed at keeping the elderly self-reliant for as long as possible, emphasis is laid on the multifaceted and subjective nature of health. It is believed to depend on people's lifestyles, life experiences, and health awareness, with individual lifestyle modifying the elements that contribute to health and functional fitness. Each person chooses behaviours that have a positive or negative impact on their health [2]. Although it is not possible to halt natural aging, it can be slowed down, prolonging an active and independent life, and thus improving the quality of life and subsequent self-assessments of health.

Long-term epidemiological studies have shown that selfassessment of health is an important predictor of mortality. As a significant measure of health, self-assessment reflects physical, mental, functional, and social health [3]. Self-assessment encompasses a comprehensive health assessment, independ- ence from others, relationships with the environment, and personal views and beliefs. It also includes an individual's perception of their status according to the culture and system of values, tasks performed, and social expectations and standards [4]. Most researchers dealing with this issue admit that there is no clear precise definition of the self-assessment of health. Generally, positive self-assessment reflects good health, ensures a considerable degree of independence, and increases freedom in making difficult decisions. But self-assessment, similarly to health itself, is a multidimensional concept.

In preventing aging, it is important not only to identify the problem but to eliminate the factors that affect the independence of the individual. The greatest threat to self-reliance is disease and the associated lack of movement. The reluctance to undertake systematic physical activity contributes to the emergence of many diseases, especially civilisation diseases. As age progresses, this self-reliance diminishes. It is essential to maximally prolong the independence of the elderly [5], especially through physical mobilisation. Acquiring information on factors affecting the life skills, self-reliance, and quality of life of the elderly can help create better conditions and shape an environment which is favourable for aging.

Old age is usually a reflection of earlier life. The aging cycle of a given community can be associated with the process of improving their health (physical, social, and mental), which enables the elderly to participate actively in society without age- 
related discrimination. If neglected, aging can become a solely negative process affecting various spheres of life.

The aim of the study was to determine the self-assessment of the health status of people aged 45-89 physically active at present and in the past.

\section{Material and methods}

Over the past few years, research has been conducted on the physical activity of the elderly at both the Faculty of Physical Culture of the Poznań Academy of Physical Education in Gorzów Wielkopolski and the Faculty of Physical Culture and Health Promotion of the University of Szczecin. As part of courses related to the physical mobilisation of older people, these students conducted interviews with their closest family members (parents and grandparents).

They subsequently designed forms of physical activity that would be most beneficial for the needs of the respondents. Selecting the respondents in this way was primarily aimed at intergenerational communication, showing the young the problems of old age and the needs of the elderly. The study used purposeful sampling involving 300 of the parents or grandparents of the students, divided into the following WHO age categories: 45-59 years, $60-74$ years, and $75-89$ years [6].

The study was conducted by means of a diagnostic survey using a questionnaire and interview. The information obtained was supplemented by observations and uncategorised interviews conducted among the students. Qualitative and quantitative analyses were performed using standard statistical methods, that is frequency of traits, chi-square independence tests, and correspondence analyses [7]. The analyses were performed using Statistica 12 software (StatSoft). The statistical significance of the relationships studied was set at $\mathrm{p} \leq 0.05$.

\section{Results}

The majority of respondents were women (62\%), most of whom were aged 60-74 years (51.6\%) (Tab. 1). Men predominated in the group of 45- to 59-year-olds. Out of all respondents, $50.1 \%$ were grandmothers, $25.1 \%$ were grandfathers, and parents constituted the rest $(24.8 \%)$. The inhabitants of cities were dominant in the sample (56.6\%). Among the people in the 45-59 age group, there were fewer rural dwellers compared to urban dwellers ( $23.8 \%$ vs. $39 \%$ of the entire population, respectively). In the group of 75- to 89-year-olds, more people lived in rural areas than in urban ones $(25.4 \%$ vs. $15.9 \%$, respectively) ( $\mathrm{p}=0.0122$ for $\chi^{2}$ test $)$. Respondents, like most Poles, were married $(67.8 \%)$. The share of widowed people was high $(20.1 \%)$, and much higher in those aged above $60(48.3 \%)$ ( $\mathrm{p}=0.0000$ for $\chi^{2}$ test). Nearly 40 percent $(39.1 \%)$ of respondents were employed, mainly those aged $45-59$, but also some in the $60-75$ group (67.2\% and $31.1 \%$, respectively) $\left(\mathrm{p}=0.0000\right.$ for $\chi^{2}$ test). The respondents had mainly primary $(47.0 \%)$ and secondary education (30.7\%); 18\% had university education, with the highest percentage of these persons found in the group of 45 - to 59 -year-olds (57.4\%). Among persons aged $75-89$ years, those with primary education constituted the largest group. In this age group, there were problems establishing the education levels $(4.3 \%)$, which is why we decided not to include this category in our analysis. Problems associated with the exact determination of the education level, especially in older age groups, have also been reported in national demographic studies [1].

Self-assessment of health status, in the context of demographic determinants, is presented in Table 2 . We found some
Table 1. Demographic data of the respondents ( $\chi 2$ independence test)

\begin{tabular}{|c|c|c|c|c|c|c|}
\hline \multirow{2}{*}{$\begin{array}{c}\text { Characteris- } \\
\text { tics }\end{array}$} & \multicolumn{3}{|c|}{ Age categories (\%) } & \multicolumn{2}{|c|}{$\begin{array}{c}\text { Total } \\
(n=300)\end{array}$} & \multirow{2}{*}{$\begin{array}{c}p \text { for the } \\
\text { test } X^{2}\end{array}$} \\
\hline & $\begin{array}{c}45-59 \\
\text { years } \\
(n=98)\end{array}$ & $\begin{array}{c}60-74 \\
\text { years } \\
(n=140)\end{array}$ & $\begin{array}{c}75-89 \\
\text { years } \\
(n=62)\end{array}$ & $n$ & $\%$ & \\
\hline $\begin{array}{l}\text { Gender: } \\
\text { Female } \\
\text { Male }\end{array}$ & $\begin{array}{l}29.1 \\
38.6\end{array}$ & $\begin{array}{l}51.6 \\
38.6\end{array}$ & $\begin{array}{l}19.3 \\
22.8\end{array}$ & $\begin{array}{l}186 \\
114\end{array}$ & $\begin{array}{l}62.0 \\
38.0\end{array}$ & $\begin{array}{c}\text { non- } \\
\text { significant }\end{array}$ \\
\hline $\begin{array}{l}\text { Role in family: } \\
\text { Grandfather } \\
\text { Grandmother } \\
\text { Father } \\
\text { Mother }\end{array}$ & $\begin{array}{c}9.4 \\
11.3 \\
100.0 \\
100.0\end{array}$ & $\begin{array}{c}57.3 \\
64.7 \\
- \\
-\end{array}$ & $\begin{array}{c}33.3 \\
24.0 \\
- \\
-\end{array}$ & $\begin{array}{c}75 \\
150 \\
37 \\
37\end{array}$ & $\begin{array}{l}25.1 \\
50.1 \\
12.4 \\
12.4\end{array}$ & - \\
\hline $\begin{array}{l}\text { Place of } \\
\text { residence: } \\
\text { Rural } \\
\text { Urban }\end{array}$ & $\begin{array}{l}39.0 \\
23.8\end{array}$ & $\begin{array}{l}45.1 \\
50.8\end{array}$ & $\begin{array}{l}15.9 \\
25.4\end{array}$ & $\begin{array}{l}164 \\
126\end{array}$ & $\begin{array}{l}56.6 \\
43.4\end{array}$ & 0.0122 \\
\hline $\begin{array}{l}\text { Marital status: } \\
\text { Single } \\
\text { Married } \\
\text { Widowed } \\
\text { Divorced }\end{array}$ & $\begin{array}{c}27.6 \\
39.6 \\
8.3 \\
71.4\end{array}$ & $\begin{array}{l}65.5 \\
44.1 \\
48.3 \\
14.3\end{array}$ & $\begin{array}{c}6.9 \\
16.3 \\
43.4 \\
14.3\end{array}$ & $\begin{array}{c}29 \\
202 \\
60 \\
7\end{array}$ & $\begin{array}{c}9.7 \\
67.8 \\
20.1 \\
2.4\end{array}$ & 0.0000 \\
\hline $\begin{array}{l}\text { Employment: } \\
\text { Yes } \\
\text { No }\end{array}$ & $\begin{array}{l}67.2 \\
10.5\end{array}$ & $\begin{array}{l}31.1 \\
56.4\end{array}$ & $\begin{array}{c}1.7 \\
33.1\end{array}$ & $\begin{array}{l}116 \\
181\end{array}$ & $\begin{array}{l}39.1 \\
60.9\end{array}$ & 0.0000 \\
\hline
\end{tabular}

Table 2. Demographic characteristics and self-assessment of health status ( $\chi^{2}$ independence test)

\begin{tabular}{|c|c|c|c|c|c|c|c|}
\hline \multirow{2}{*}{$\begin{array}{l}\text { Character- } \\
\text { istics }\end{array}$} & \multicolumn{4}{|c|}{ Self-assessment (\%) } & \multicolumn{2}{|c|}{$\begin{array}{c}\text { Total } \\
(\mathrm{n}=300)\end{array}$} & \multirow{2}{*}{$\begin{array}{c}p \text { for the } \\
X^{2} \text { test }\end{array}$} \\
\hline & $\begin{array}{c}\text { Very } \\
\text { good } \\
(n=29)\end{array}$ & $\begin{array}{c}\text { Good } \\
(n=118)\end{array}$ & $\begin{array}{l}\text { Moderate } \\
(n=118)\end{array}$ & $\begin{array}{l}\text { Bad and } \\
\text { very bad } \\
(n=35)\end{array}$ & $n$ & $\%$ & \\
\hline $\begin{array}{l}\text { Age (years): } \\
45-59 \\
60-74 \\
75-89\end{array}$ & $\begin{array}{c}51.7 \\
48.0 \\
0.3\end{array}$ & $\begin{array}{c}48.3 \\
42.4 \\
9.3\end{array}$ & $\begin{array}{l}17.0 \\
52.5 \\
30.5\end{array}$ & $\begin{array}{l}17.1 \\
40.0 \\
42.9\end{array}$ & $\begin{array}{c}98 \\
140 \\
62\end{array}$ & $\begin{array}{l}32.7 \\
46.7 \\
20.6\end{array}$ & $\begin{array}{c}p= \\
0.0000\end{array}$ \\
\hline $\begin{array}{l}\text { Gender: } \\
\text { Female } \\
\text { Male }\end{array}$ & $\begin{array}{l}65.5 \\
34.5\end{array}$ & $\begin{array}{l}59.3 \\
40.7\end{array}$ & $\begin{array}{l}64.4 \\
35.6\end{array}$ & $\begin{array}{l}60.0 \\
40.0\end{array}$ & $\begin{array}{l}186 \\
114\end{array}$ & $\begin{array}{l}62.0 \\
38.0\end{array}$ & $\begin{array}{c}\text { non- } \\
\text { significant }\end{array}$ \\
\hline $\begin{array}{l}\text { Place of } \\
\text { residence: } \\
\text { Urban } \\
\text { Rural }\end{array}$ & $\begin{array}{l}57.1 \\
42.9 \\
\end{array}$ & $\begin{array}{l}65.2 \\
34.8\end{array}$ & $\begin{array}{l}52.6 \\
47.4\end{array}$ & $\begin{array}{c}7.9 \\
15.9 \\
\end{array}$ & $\begin{array}{l}164 \\
126 \\
\end{array}$ & $\begin{array}{l}56.6 \\
43.5 \\
\end{array}$ & $\begin{array}{c}p= \\
0.0418\end{array}$ \\
\hline $\begin{array}{l}\text { Marital status: } \\
\text { Single } \\
\text { Married } \\
\text { Widowed } \\
\text { Divorced }\end{array}$ & $\begin{array}{c}17.2 \\
79.3 \\
3.5 \\
-\end{array}$ & $\begin{array}{c}8.6 \\
74.4 \\
12.8 \\
4.2\end{array}$ & $\begin{array}{l}10.3 \\
59.0 \\
29 . \\
1.7\end{array}$ & $\begin{array}{c}5.7 \\
65.7 \\
28.6 \\
-\end{array}$ & $\begin{array}{c}29 \\
202 \\
60 \\
7\end{array}$ & $\begin{array}{c}9.7 \\
67.8 \\
20.1 \\
2.4\end{array}$ & - \\
\hline $\begin{array}{l}\text { Employment: } \\
\text { Yes } \\
\text { No }\end{array}$ & $\begin{array}{l}69.0 \\
31.0\end{array}$ & $\begin{array}{l}53.0 \\
47.0\end{array}$ & $\begin{array}{l}28.0 \\
72.0\end{array}$ & $\begin{array}{c}5.7 \\
94.3\end{array}$ & $\begin{array}{l}116 \\
181\end{array}$ & $\begin{array}{l}39.1 \\
60.9\end{array}$ & $\begin{array}{c}p= \\
0.0000\end{array}$ \\
\hline $\begin{array}{l}\text { Role in family: } \\
\text { Grandfather } \\
\text { Grandmother } \\
\text { Father } \\
\text { Mother }\end{array}$ & $\begin{array}{c}6.6 \\
8.0 \\
13.5 \\
18.9\end{array}$ & $\begin{array}{l}32.9 \\
33.3 \\
59.5 \\
56.8\end{array}$ & $\begin{array}{l}44.7 \\
46.7 \\
21.6 \\
16.2\end{array}$ & $\begin{array}{l}15.8 \\
12.0 \\
5.4 \\
8.1\end{array}$ & $\begin{array}{c}76 \\
150 \\
37 \\
37\end{array}$ & $\begin{array}{l}25.2 \\
50.0 \\
12.3 \\
12.3\end{array}$ & $\begin{array}{c}p= \\
0.0009\end{array}$ \\
\hline
\end{tabular}


statistically significant relationships between self-rated health and the age of the respondents, their place of residence, their being parents or grandparents, and their employment status $\left(\mathrm{p}=0.0000, \mathrm{p}=0.0418, \mathrm{p}=0.0009\right.$, and $\mathrm{p}=0.0000$ for $\chi^{2}$ test, respectively). Very good ( $51.7 \%$ and $48 \%$ of all "very good" answers, respectively) or good (48.3\% and $42.4 \%$, respectively) health status was most often reported by those aged 45-59 and 60-74 years. At the same time, more than half of the 60- to 74-year-olds reported moderate health status. People aged 7589 had the highest number of bad and very bad scores (42.9\%).

City dwellers were characterised by a higher self-assessment of health status (in the very good, good, and moderate categories), while those living in rural areas were twice as likely to report bad and very bad health. Depending on their role in the family (mainly related to age), fathers and mothers generally rated their health as good (59.5\% and $56.8 \%$, respectively), while grandparents and grandmothers saw it as moderate $(44.7 \%$ and $46.7 \%$, respectively) or bad and very bad (15.8\% and $12 \%$, respectively). Statistically significant relationships were found between employment and self-assessment of health. Working individuals dominated the "very good health" (69\%) or "good" (53\%) categories, while the non-employed were the majority of those who indicated "moderate" (72\%) or "bad and very bad" health status (94.3\%). There was no relationship between selfassessment of health status and gender or marital status.

On the other hand, we found a relationship with physical recreation and meeting with friends $(p=0.0000$ and $p=0.0129$ for test $\chi^{2}$, respectively) (Tab. 3). Very good (79.3\%) or good $(55.1 \%)$ self-assessments of health dominated among those involved in physical recreation. People frequently meeting their friends in their free time were the majority of those reporting a good state of health (51.7\%). This form of spending time was also preferred by respondents who rated their health as moderate $(35.6 \%)$ or bad and very bad $(37.1 \%)$.

The self-assessment of one's health is influenced by many factors, including previous physical activity (Tab. 4). Engaging in recreation, rehabilitation, and travelling as well as going away on holiday in the previous year, going to a sanatorium, and being a professional athlete in the past showed a statistically significant correlation with the self-assessed health status $(\mathrm{p}=$ 0.0017, $\mathrm{p}=0.0215, \mathrm{p}=0.0000, \mathrm{p}=0.0000, \mathrm{p}=0.0048$, and $\mathrm{p}=0.0026$ for $\chi^{2}$ test, respectively). People who declared participating in physical recreation and sports as well as travelling and going away on holiday had the highest self-assessment of health status (very good). Those reporting engaging in rehabilitation or going to a sanatorium had moderate, bad, or very bad health assessments.

Based on the conversations with parents and grandparents, the students designed dedicated exercise programmes. If the respondents were already active, they were proposed to vary the activities and distribute them more evenly during the week. All forms of exercise were discussed with the individual respondents and were then adjusted to their needs (Fig. 1).

The exercises were mostly gym exercises (36\%), rehabilitation $(28.7 \%)$, fitness exercises $(26.7 \%)$, and Nordic walking $(26.7 \%)$. They also included forms that were new to the respondents, namely exercises with easily available equipment (fitballs, latex bands, rollers, elliptical trainers, steps, and 1-kg or $2-\mathrm{kg}$ dumbbells) (12\%), on stationary bikes $(6.7 \%)$, and in fitness parks etc. located outdoors (6\%). On average, if implemented, the programmes prepared by the students increased the number of rehabilitation exercises 7 times (from $4 \%$ to $28.7 \%$ ). The use of stationary bikes and various other exercise equipment was associated with the different motor limitations of the elderly. It is
Table 3. Leisure-time activities and self-assessment of health status $\left(\chi^{2}\right.$ independence test)

\begin{tabular}{|c|c|c|c|c|c|c|c|}
\hline \multirow[b]{2}{*}{$\begin{array}{l}\text { Leisure-time } \\
\text { activities }\end{array}$} & \multicolumn{4}{|c|}{ Self-assessment of health (\%) } & \multicolumn{2}{|c|}{ Total } & \multirow[b]{2}{*}{$\begin{array}{c}p \text { for the } x^{2} \\
\text { test }\end{array}$} \\
\hline & $\begin{array}{c}\text { Very } \\
\text { good } \\
(n=29)\end{array}$ & $\begin{array}{c}\text { Good } \\
(n=118)\end{array}$ & $\begin{array}{l}\text { Moderate } \\
(n=118)\end{array}$ & $\begin{array}{l}\text { Bad and } \\
\text { very bad } \\
(n=35)\end{array}$ & $n$ & $\%$ & \\
\hline $\begin{array}{l}\text { Physical } \\
\text { recreation }\end{array}$ & 79.3 & 55.1 & 44.9 & 25.7 & 150 & 50.0 & 0.0000 \\
\hline $\begin{array}{l}\text { Social } \\
\text { activity }\end{array}$ & 24.1 & 19.5 & 31.4 & 17.1 & 73 & 24.3 & $\begin{array}{c}\text { non- } \\
\text { significant }\end{array}$ \\
\hline Reading & 51.7 & 51.7 & 65.3 & 54.3 & 172 & 57.3 & $\begin{array}{c}\text { non- } \\
\text { significant }\end{array}$ \\
\hline Family visits & 37.9 & 41.5 & 48.3 & 48.6 & 134 & 44.7 & $\begin{array}{c}\text { non- } \\
\text { significant }\end{array}$ \\
\hline Travelling & 20.7 & 28.0 & 25.4 & 11.4 & 73 & 24.3 & $\begin{array}{c}\text { non- } \\
\text { significant }\end{array}$ \\
\hline Gardening & 51.7 & 55.9 & 47.5 & 45.7 & 153 & 51.0 & $\begin{array}{c}\text { non- } \\
\text { significant }\end{array}$ \\
\hline Hobby & 37.9 & 27.1 & 36.4 & 25.7 & & & $\begin{array}{c}\text { non- } \\
\text { significant }\end{array}$ \\
\hline $\begin{array}{l}\text { Meeting with } \\
\text { friends }\end{array}$ & 24.1 & 51.7 & 35.6 & 37.1 & 123 & 41.0 & 0.0129 \\
\hline $\begin{array}{l}\text { University } \\
\text { of the Third } \\
\text { Age, Senior } \\
\text { Clubs }\end{array}$ & 17.2 & 8.5 & 9.3 & 11.4 & 30 & 10.0 & $\begin{array}{c}\text { non- } \\
\text { significant }\end{array}$ \\
\hline
\end{tabular}

* Total percent levels are not 100, because the respondents could select many options.

Table 4. Relationships between self-assessment of health and various forms of physical activities and health-promoting behaviours in the past ( $\chi^{2}$ independence test)

\begin{tabular}{|c|c|c|c|c|c|c|c|}
\hline \multirow[b]{2}{*}{ Physical activity } & \multicolumn{4}{|c|}{ Self-assessment of health (\%) } & \multicolumn{2}{|c|}{ Total } & \multirow[b]{2}{*}{$\begin{array}{c}p \text { for the } \\
x^{2} \text { test }\end{array}$} \\
\hline & $\begin{array}{c}\text { Very } \\
\text { good } \\
(n=29)\end{array}$ & $\begin{array}{c}\text { Good } \\
(n=118)\end{array}$ & $\begin{array}{c}\text { Moderate } \\
(n=118)\end{array}$ & $\begin{array}{c}\text { Bad and } \\
\text { very bad } \\
(n=35)\end{array}$ & $n$ & $\%$ & \\
\hline $\begin{array}{l}\text { Physical educa- } \\
\text { tion classes }\end{array}$ & 96.6 & 95.6 & 92.1 & 78.8 & 267 & 92.4 & $\begin{array}{c}\text { non- } \\
\text { significant }\end{array}$ \\
\hline $\begin{array}{l}\text { Physical recrea- } \\
\text { tion }\end{array}$ & 86.2 & 80.3 & 72.0 & 60.0 & 225 & 75.3 & 0.0017 \\
\hline $\begin{array}{l}\text { Travelling (in the } \\
\text { previous year) }\end{array}$ & 88.0 & 87.5 & 49.0 & 25.0 & 170 & 66.9 & 0.0000 \\
\hline Rehabilitation & 47.6 & 60.2 & 76.2 & 71.9 & 166 & 67.5 & 0.0215 \\
\hline $\begin{array}{l}\text { Activities at } \\
\text { a sanatorium }\end{array}$ & 38.1 & 41.0 & 57.3 & 74.2 & 118 & 52.2 & 0.0048 \\
\hline $\begin{array}{l}\text { Going away on } \\
\text { holiday (within the } \\
\text { past } 12 \text { months) }\end{array}$ & 72.0 & 65.6 & 27.2 & 25.0 & 112 & 47.3 & 0.0000 \\
\hline $\begin{array}{l}\text { Professional } \\
\text { sports in the past }\end{array}$ & 37.9 & 35.3 & 17.8 & 14.3 & 78 & 26.2 & 0.0026 \\
\hline
\end{tabular}

worth noting that the students prepared a similar number of the various forms of activity (more than 20) for both the 45-59 and 60-74 age groups. For the respondents older than 74 , they prepared 7 forms of exercise, mainly rehabilitation exercises. 


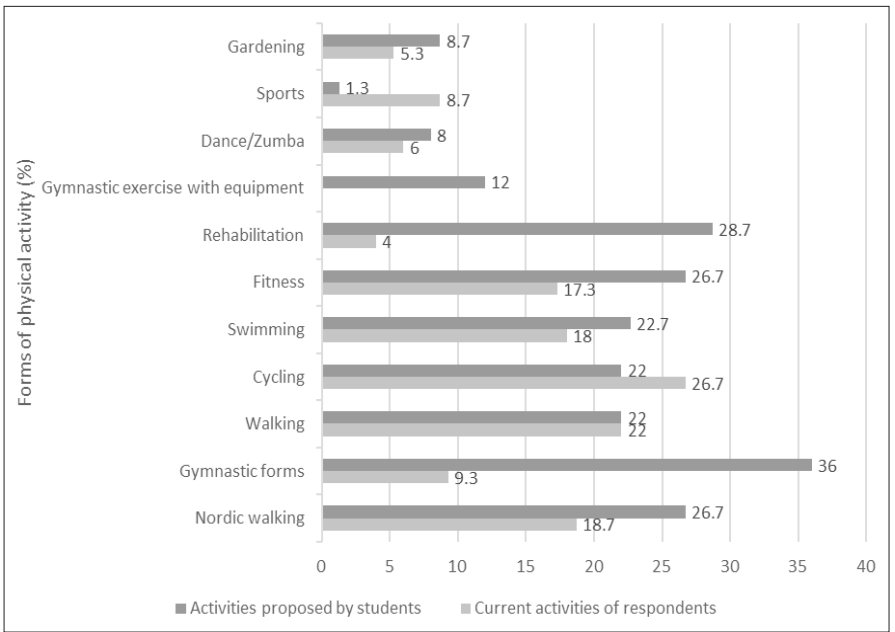

Figure 1. Forms of physical activity of the respondents against the programmes prepared for them by the students

The relationships between self-assessment of health and participation in physical recreation of persons with different socio-demographic conditions are presented comprehensively on the basis of the use of multivariate correspondence analysis (Fig. 2), combined with chi-square independence tests (Tab. 1, 2 , and 3). Two selected dimensions (first and second) accounted for $31.27 \%$ of the total $\chi^{2}$ value. By performing a graphical interpretation of the results of the correspondence analysis in relation to the two dimensions, we outlined the categories of the age examined (45-59, 60-74, and 75-89), present participation (or lack thereof) in physical recreation ( $\mathrm{R}$ - engaging in recreation; $\mathrm{NR}$ - not engaging in recreation), and self-assessment of health (A, B, C, or D).

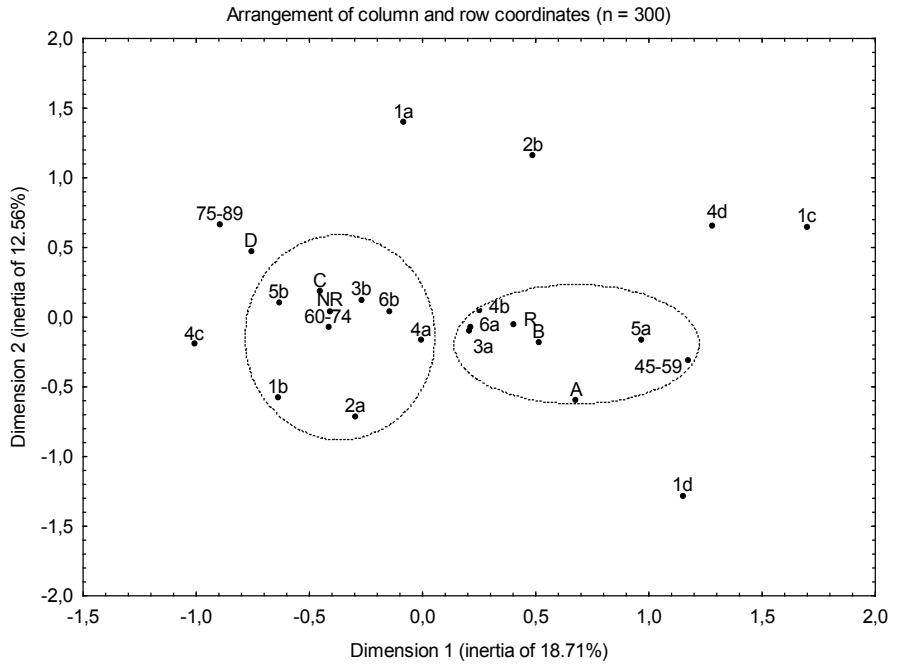

Figure 2. Relationships between self-assessment of health and current participation in physical activities (multivariate correspondence analysis)

People aged 45-59 participated in physical recreation more often (R), had very good (A) and good self-assessment of health (B), were urban residents (3a), were single (4a) or married (4b), and were more often employed (5a). These people also preferred meeting with friends as a form of spending leisure time (6a). People aged 60-74 who were grandmothers (lb), mainly rural residents ( $3 b)$, not employed (5a), not maintaining social contact during leisure (6b), and not participating in physical recreation (NR) assessed their health as moderate $(C)$. Peripheral positions were occupied by people aged 75-89, with poor and very poor health status (D), grandfathers (la) and fathers (lc), men (2b), and widowed (4c) and divorced (4d) persons.

Figure 3 shows the relationship between self-assessment and respondents' physical activity in the past. The selected two dimensions (first and second) accounted for $35.53 \%$ of the total value of $\chi^{2}$. People aged 45-59 with very good (A) and good selfassessment of health (B) had travelled in the previous year (la) and had also gone away on holiday (4b). Persons aged 60-74 who had participated in physical recreation in the past $(R)$, had not been professional athletes ( $5 b$ ), had gone to a sanatorium (3a), had undergone rehabilitation in the past (2a), and had not gone away on holiday within the past 12 months (4b) assessed their health as moderate $(C)$. The oldest respondents (75-89) who had not travelled in the previous year $(\mathrm{lb})$ rated their health as bad and very bad (D). Peripheral positions were taken by those who had been professional athletes (5a), had undergone rehabilitation in the past ( $2 \mathrm{~b})$, had not gone to sanatoriums ( $3 \mathrm{~b})$ and those who had never participated in physical recreation (NR).

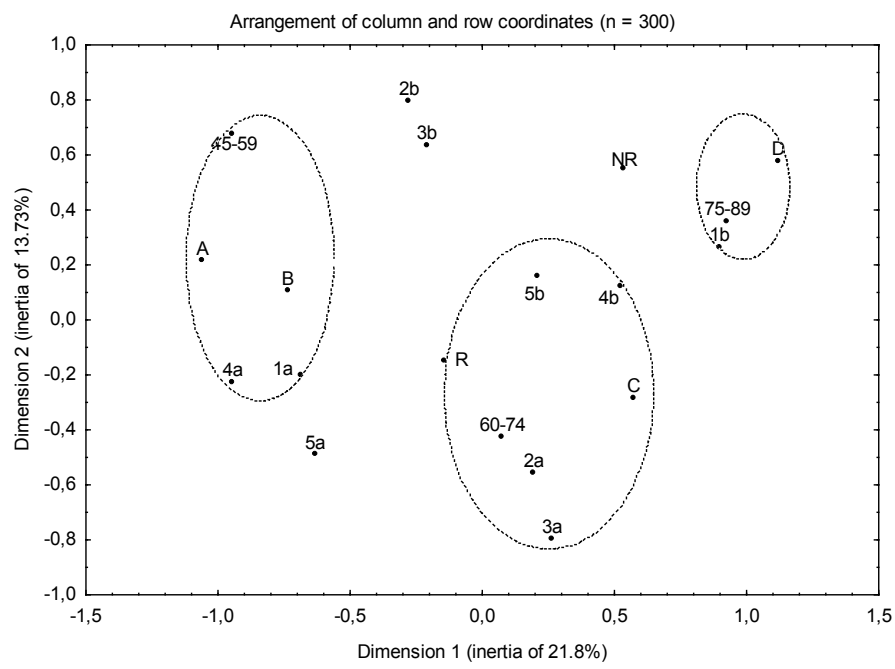

Figure 3. Relationship between self-assessment of health and previous participation in physical activities (multivariate correspondence analysis)

\section{Discussion}

Health behaviours, including physical activity, are important elements of human life. They are of particular relevance in older people because they are indicative of the limits of their adaptation to new life situations, which is impacted by their previous and present social status. These behaviours make it possible to determine an elderly person's degree of satisfaction with their psychophysical health, physical activity, and social life and contribute to their quality of life.

The majority of respondents were women (62\%), and this proportion increased with age. The cause of this situation in Poland is the high mortality rate among men, for example due to cardiovascular disease and cancer. Despite a decline over the last quarter of a century, these health issues still account for more than half of all deaths among the elderly. In 2012, they caused $54 \%$ of deaths, of which nearly a quarter were due to coronary 
heart disease (13\%) and atherosclerosis (11\%) [1]. The mortality rate of both sexes is similar after they have reached the age of 90 .

Women assessed their health higher than men in each age category, as did city dwellers who were mothers and fathers and people aged 45-59 and 60-74. The health self-assessment scores among people over 75 years of age are certainly associated with the number of illnesses they suffer from [1] and the accompanying weakness, limited range of movement, and pain which may lead to reduced physical activity, lower overall fitness, worse mental well-being, and loss of self-reliance.

Survey data on the subjective self-assessment of health collected by the Polish National Statistical Office (GUS) show that the health status of Polish adults, including those aged 65 and over, is constantly improving. However, a recent GUS survey from 2012 showed that only one-eighth of elderly persons in Poland (13\%) rated their health as at least good, 45\% declared moderate health (neither good nor bad), and the remaining $42 \%$ indicated a bad or very bad health condition (in 2005, such ratings were over 50\%). Women are more sceptical about their health than men, and we continue to observe this pattern in all age groups - not just the elderly. Self-assessment of health decreases with age. In studies that included only these two categories (self-assessment and age), a higher self-assessment of health was reported among women aged 45-59 years [8].

Often among older people we notice a withdrawal from social life, a weakening of contacts with others, a decision to stop pursuing their interests, and a lack of self-esteem. In addition, professional deactivation changes the social roles of a person from an employee to the role of someone receiving a retirement pension or someone dependent on others. This situation, which is strongly influenced by previous relationships, changes the quality of life of people in post-working age [9], and has an influence on their psychophysical well-being.

The components of successful aging are directly and indirectly related to the occupation of an individual, especially its continuation in the later stages of life, in particular after retirement. Recently retired persons initially perceive it as a holiday lasting the entire year and time for relaxation, but with time, their opinions become definitely more negative. Pensioners start to experience financial shortages and begin to have problems with their free time due to a lack of funds. Many struggle to cope with their new situation, which significantly lowers their satisfaction with life [10].

Bambrick and Bonder [9] argue that people assess a given activity according to its significance in their previous periods of life. It means that those for whom occupation was the most important thing in life will still tend to treat it as a priority in the later stages of life. If most satisfaction came from activities not related to their occupation, then this will be similar in the future [9].

In this study, we confirmed a relationship between continued employment in respondents and their self-assessment of health. Employment is related to satisfaction, independence, and the need for an active lifestyle. This was also found in patients of post-working age who returned to work after liver transplantation; compared to those who did not go back to work after the surgery, they reported a significantly higher quality of life as a result of their health status and higher levels of physical activity [11]. Professional duties help the elderly to maintain their self-esteem and sense of belonging. For many, work is one of the few chances to meet other people and keep in touch with the It has been confirmed in many studies that physical activity has a profound effect on health [12-22]. Engaging in physical recreation is of fundamental importance for health and geron- tological prevention. Participation in specific physical activities is determined not only by age, but also by current health, physical fitness, general fitness, motivation, and experience. A lack of physical activity is one of the most important modifiable risk factors for many diseases. Our study showed a higher self-assessment of health in those who were currently or had previously been involved in physical recreation as well as those participating in physical education classes, former professional athletes, and persons who had been travelling and going away on holiday, among others within the past year. Activity, including physical activity, allows the elderly to be independent and play social roles, as well as preventing social isolation, loneliness, and premature mortality [23]. Undertaking such forms of activity is also evidence of concern for one's health [24]. Physical activity is an indispensable part of health prevention, and, in the case of various conditions, it is also a part of therapy. It has utilitarian functions directly connected with the sphere of daily life, maintenance of independence in life, and mental relaxation. Many publications emphasise that elderly people who lack activity tend to declare poor or moderate health and are at increased risk of depressive symptoms [25, 26].

Researchers point to the negative effects of a sedentary lifestyle on human functioning: this type of lifestyle may be an indirect or direct cause of death [27]. The lack of movement not only has negative effects in the physical sphere, but it also has a great impact on mental well-being. Guszkowska and Kozdroń [28] attempted to determine the mood changes that occur in older women due to physical activity and its deficit. The results of the study showed that regular exercise significantly reduced anxiety in this group [28].

Aging persons tend to become less and less physically active, which is related, among others, to changes occurring within the locomotor system, loss of muscle strength and flexibility, motor coordination disorders, and decreased physical capacity, as well as decreased lung capacity, connective tissue stiffness, arthralgia, and neurodevelopmental disorders. Increased susceptibility to fractures and frequent falls may lead to full or partial disability and dependence on others. Involutional changes can be slowed down by an adequate level of physical activity. Unfortunately, however, most elderly people experience a marked decrease in activity, which is often limited to daily activities such as shopping, cooking, and cleaning [29].

Many authors report a positive correlation between moderate physical activity and positive health habits. Persons who practise sports more frequently pay attention to proper nutrition, the avoidance of stimulants, regular rest, and active leisure activities $[24,30]$ and are more optimistic compared to those who do not engage in sports [31]. Old age is the most diverse phase of life because it also depends on previous periods [32]. It therefore seems justified to promote healthy lifestyle and prevent chronic illnesses, which is crucial for the maintenance of health and self-reliance until the late stages of life.

One of the aims of the purposeful selection of respondents was to make the students familiar with old age, the needs of the elderly, and the methods of working with them. Prior to the experiment, the students were asked to express how they imagined their old age. They perceived it as a chance to participate in recreation, travel, engage in tourism, visit their family, as well as pursue their interests, engage in social life, read, and undertake social activity. More than one-fourth of the students had not thought about old age yet.

Based on the health status, physical fitness, mental abilities, and self-reliance of their closest relatives (parents and grandparents), the physical education students were very opti- 
mistic about their own old age. Their anticipated high fitness in old age was related to the very good health of their mothers and fathers. The expected self-reliance in old age, on the other hand, was related to their observation of their fathers and grandfathers [33]. No such relationship was observed for mothers and grandmothers, which should be ascribed to the higher level of sports activity among Polish males. The students only took into account any form of old-age disability if they had experienced it in their own family.

The positive image the students had of older people in the closest family was associated with the fact that these persons were able to transmit values and family traditions and participate in the upbringing of the younger generation. However, a comparison of values ascribed by the students to the elderly and those actually reported by them shows discrepancies. The students perceived their grandparents as valuing health, family, religion, and peace and quiet. Although grandparents did value these things, they were much less important to them than their grandchildren thought. These aspects of life were lower in importance than work, physical fitness, financial security, and self-reliance.

These discrepancies result from students seldom contacting their grandparents and having little interest in their lives, despite the declared positive emotional bonds. Most of the students lived with parents or alone, and much less frequently together with their grandparents. The surveys with the oldest family members, performed mainly during the holidays, were an opportunity for direct contact. Although intended for just 30 minutes, the interview sometimes took a few hours, and the subject recurred in the following days, during walks or housework.

The conversations with their grandparents, initially meant to refer to health issues only, gradually diverged from this topic and often referred to the past of their relatives. The grandparents surprised their grandchildren with their knowledge of $20^{\text {th }}$ century history and presented interesting interpretations of socio-economic facts. They often mused - with wit and distance - about the history of the closest family. The students reported that their grandparents were dependable and interested in the problems of the youth of today and that they could learn diligently from their grandchildren, for example when acquiring skills in using their phone, tablet, or computer. The students indicated that the elderly must be educated on changing behaviours in daily life, ways to cope with modern daily life (especially when visiting various institutions), new technologies, and ways of spending free time.

Students also pointed to the negative sides of old age. They associated it with certain physical characteristics (e.g. wrinkles and limited mobility), mental abilities (forgetting and repeating commonly known things), and features of emotional life (stubbornness or ill-will). The students also rarely mentioned they would like to work with the elderly in the future. Only $21.4 \%$ of female students and $8.9 \%$ of men expressed an interest in this area of work [33].

The students' attempts at activating their parents and grandparents facilitated contact between the generations and familiarised the young with the old and old age. They showed the importance of experience, in that it can offset deficiencies in formal education. The interviews promoted intergenerational family contacts, much needed by the young and old generations. For most Poles, family values are still one of the most significant elements of life [34].

Research on the elderly is significant for identifying preventive activities. Knowledge about the types of behaviour condu- cive to health and ways to modify them, supported by positive behaviour patterns, should contribute to improving the health of society.

\section{Literature}

1. National Statistical Office. (2016). Demographics of the elderly and consequences of the aging of the Polish population in the forecast for the years 2014-2050. Report of the Department of Demographic Research and Labour Market and the Department of Social Studies and Living Standards. Warsaw: GUS. [in Polish]

2. Heszen I., Sęk H. (2012). Behavioral conditions of health and disease. In I. Heszen, H. Sęk (eds), Psychology of health (pp. 90-104). Warsaw: PWN. [in Polish]

3. Maniecka-Bryła I. (2006). Changes in the health status of the citizens of Eódź in the period of social and economic transformation (based on the example of people aged 65-74 years). Post-doctoral thesis. Uniwersytet Medyczny, Łódź. [in Polish]

4. Kotarska K., Raszeja-Wyszomirska J. (2011). The assessment of the quality of life and physical activity in patients after liver transplantation: The review of the literature. Polish Gastroenterology 18(2), 84-87.

5. Kozdroń E., Kozdroń A. (2005). Active recreation and selfreliance in old age. Tourism and Recreation 1, 166-169. [in Polish]

6. Zych A.A. (2001). Dictionary of social gerontology. Warsaw: Wydaw. Akad. "Żak”. [in Polish]

7. Van Buuren J., de Leeuw J.V. (1992). Equality constraints in multiple correspondence analysis. Multivariate Behavioral Research 27(4), 567-583.

8. Nowak M.A., Troczyńska N., Forjasz J., Nowak L. (2016). Chosen aspects of lifestyles of physically active women aged 45-59 and 60-74. Health Problems of Civilization 10(3), 3037.

9. Bambrick P., Bonder B. (2005). Older adults' perception of work. Work 24, 77-84.

10. Bałandynowic-Panfil K. (2011). The role of employment in the quality of life in old age. In D. Kałuża, P. Szukalski (eds), Quality of life of the elderly in the 21 ${ }^{\text {st }}$ century: Towards activity. Łódź: Wydawnictwo Biblioteka. [in Polish]

11. Kotarska K., Wunsch E., Kempińska-Podhorodecka A., Raszeja-Wyszomirska J., Bogdanos D., Wójcicki M. et al. (2014). Factors affecting health-related quality of life and physical activity after liver transplantation for autoimmune and nonautoimmune liver diseases: A prospective, single centre study. Journal of Immunology Research Article ID 738297. DOI: $10.1155 / 2014 / 738297$.

12. Beenackers A., Kamphuis C.B., Giskes K., Brug J., Kunst A.E., Burdorf A. et al. (2012). Socioeconomic inequalities in occupational, leisure-time, and transport-related physical activity among European adults: A systematic review. International Journal of Behavioral Nutrition and Physical Activity 29, 116-120. DOI: 10.1186/1479-5868-9-116.

13. Hupin D., Roche F., Oriol M., Garet M., Pichot V., Gremeaux V. et al. (2016). Physical activity for older adults: Even a little is good! Annals of Physical and Rehabilitation Medicine 59S:e58. DOI: 10.1016/j.rehab.2016.07.135.

14. Kaźmierczak U., Radzimińska A., Dzierżanowski M., Bułatowicz I., Strojek K., Srokowski G. et al. (2015). Benefits of regular exercise for the elderly. Journal of Education, Health and Sport 5(1), 56-68. DOI: 10.5281/zenodo.13935. [in Polish] 
15. Kozdroń E., Leś A. (2010). Physical activity in the process of successful aging. Advances of Rehabilitation 1, 49-57. [in Polish]

16. Kruk J. (2014). Health and economic costs of physical inactivity. Asian Pacific Journal of Cancer Prevention 15(18), 7499-7503. DOI: 10.7314/APJCP.2014.15.18.7499.

17. Musich S., Wang S., Hawkins K., Greame C. (2016). The frequency and health benefits of physical activity for older adults. Population Health Management 13. DOI: 10.1089/ pop.2016.0071.

18. Nowak M. (2006). Factors determining physical fitness selfevaluation and health self-evaluation in physically active women. New Medicine 9(1), 19-25.

19. Osiński W., Szeklicki R. (2012). The development of gerokinesiology: One of the most urgent challenges for physical culture. Physical activity of the elderly in scientific research (needs and benefits). Poznań: Bogucki Wydawnictwo Naukowe. [in Polish]

20. Ossowski Z., Prusik K., Prusik K., Kortas J., Wiech M., Bielawa Ł. (2014). Nordic walking training and physical fitness in elderly women. Polish Journal of Sport and Tourism 21, 253-262.

21. Sygit K. (2015). Fundamental significance of physical activity for seniors' health. Central European Journal of Sport Sciences and Medicine 12(4), 53-59. DOI: 10.18276/ cej.2015.4-06.

22. Krzepota J., Biernat E., Florkiewicz B. (2013). The physical activity of Third Age University students with various BMI. General Medicine and Health Sciences 19(2), 200-205. [in Polish]

23. Kaczmarek M., Trafiałek E. (2007). Activation of the elderly as a chance for successful aging. Polish Gerontology 15, 116118. [in Polish]

24. Nowak M. (2008). Physical activity in the healthy lifestyles of women. Poznań: AWF Poznań. [in Polish]
25. Meyer K. (2005). Aging successfully. Journal of Public Health Management and Practice 13, 177-178.

26. Stathi A., McKenna J., Fox K.R. (2003). The experiences of older people participating in exercise referral schemes. Journal of the American Society of Echocardiography 124, 1823.

27. Cooper A.R., Sebire S., Montgomery A.A., Peters T.J., Sharp D.J., Jackson N. et al. (2012). Sedentary time, breaks in sedentary time and metabolic variables in people with newly diagnosed type 2 diabetes. Journal of Diabetology 55(3), 589-599. DOI: 10.1007/s00125-011-2408-x.

28. Guszkowska M., Kozdroń A. (2009). The effect of exercise on the emotional states of elderly women. Polish Gerontology 17(2), 71-78. [in Polish]

29. Sun F., Norman I.J., While A.E. (2013). Physical activity in older people: A systematic review. BMC Public Health 13, 449. DOI: 10.1186/1471-2458-13-449.

30. Łubkowska W., Szark-Eckardt M., Juszczyk A., Zając M., Stępień-Słodkowska M., Mroczek B. et al. (2016). Assessment of impact of the computer work station on the risk of musculoskeletal system diseases in banking sector employees. Lase Journal of Sport Science 7(2), 93-106.

31. Lipowski M. (2012). Level of optimism and health behavior in athletes. Medical Science Monitor 18(1), 39-43. DOI: 10.12659/MSM.882200.

32. Nowicka A. (2006). Old age as a phase of human life. In A. Nowicka (ed.), Selected problems of elderly people (pp. 20-22). Kraków: Impuls. [in Polish]

33. Nowak M.A., Nowak L. (2012). Old age and aging in the opinion of students. In D. Umiastowska (ed.), Physical activity of people in different ages, vol. 16 (pp. 113-123). Szczecin: Wydaw. Promocyjne "Albatros".

34. Czapiński J., Panek T. (ed.) (2015). Social diagnosis 2015. Conditions and quality of life in Poland. Warsaw: Rada Monitoringu Społecznego. [in Polish]

Submitted: April 12, 2017

Accepted: June 16, 2017 